\title{
PENERAPAN METODE BERNYANYI DALAM MENINGKATKAN \\ PENGUASAAN MUFRADAT DALAM PEMBELAJARAN BAHASA ARAB DI RAODHATUL ATHFAL
}

\author{
Ridwan $^{1}$, A.Fajar Awaluddin ${ }^{2}$ \\ ridwandanarsyil@gmail.com ${ }^{1}$ \\ STAI Al-Gazali Bone ${ }^{1}$, IAIN Bone ${ }^{2}$
}

\begin{abstract}
This study aims to improve the acquisition of Arabic vocabulary in early childhood with singing techniques. Children of all ages are basically happy to listen, sing and learn with songs. Therefore, music in general is an important part of the teaching-learning process for young students. The results showed that early childhood students enjoyed learning Arabic by singing and it was easier to remember the vocabulary taught by the teacher. Thus, it can be concluded that the singing technique is able to improve the mastery of early childhood Arabic vocabulary especially for students of the Raodhatul Athfal Ma'had Hadits Al-Junaidiyah Blue Bone.
\end{abstract}

Keywords: Singing technique, vocabulary mastery, Arabic

Diterima: 11-07-2019, Direview: 22-07-2019, Diterbitkan: 16-08-2019

\section{PENDAHULUAN}

Dalam pembelajaran bahasa asing, kosakata adalah hal penting dari semua aspek bahasa asing yang harus dipahami peserta didik. Penguasaan serta pemahaman kosakata (mufradat) memiliki faedah yang sangat penting sekali, karena penguasaan kosakata bermanfaat bagi yang ingin menulis serta belajar tentang bahasa Arab (Khulli, M. Ali, 1986:32). Seiring dengan perkembangan zaman, peserta didik usia dini tidak hanya dituntut pandai dalam berbahasa Indonesia akan tetapi perlu dikenalkan dengan bahasa asing seperti bahasa Arab. 
Bahasa Arab adalah bahasa pengantar internasional yang amat penting. Karena Negara Indonesia merupakan bagian dari negara-negara yang ada di dunia, oleh karenanya apabila bangsa Indonesia hendak maju dan berkembang, maka sepatutnya dapat berinteraksi di bidang politik, ekonomi, budaya, sosial, keamanan, pertahanan, dan pendidikan dengan berbagai negara di dunia melalui perantara bahasa internasional yaitu bahasa Inggris, tetapi bahasa Arab juga bisa dipelajari untuk berinteraksi dengan warga Arab.

Negara yang maju adalah negara yang peduli akan nasib generasi mudanya, sedangkan bahasa termasuk salah satu kunci utama untuk generasi bangsa dalam membuka jendela dunia. Maka seyogyanya generasi penerus bangsa kita, perlu dikenalkan dan dipahamkan bahasa Arab. walaupun bahasa Arab bukan termasuk komponen yang wajib dalam kurikulum PAUD/TK/RA. Akan tetapi, tidaklah salah jika semenjak usia dini atau masa emas (golden age) di mana usia 0-6 tahun adalah masa peka dan pesatnya perkembangan otak anak, maka sangat tepat jika anak usia dini dikenalkan dengan bahasa Arab. Oleh karenanya penguasaan kosakata bahasa Arab yang merupakan dasar agar kita dapat berinteraksi dan berkomunikasi satu dengan yang lainnya, perlu mendapatkan perhatian dan perlu ditingkatkan pada anak usia dini.

Manusia mengekspresikan berbagai bentuk peristiwa dalam kehidupan sehari-hari dengan mengolah kata-kata yang tersusun dalam kalimat untuk itu penguasaan kosakata adalah suatu hal yang penting untuk dipahami sebagai syarat untuk peserta didik yang ingin mahir dalam berbahasa. Sebab kualitas berbahasa seseorang akan tergantung pada kualitas kosakata yang dimiliki. Semakin besar kosakata yang dimiliki semakin besar pula peluang untuk terampil berbahasa (Tarigan, 1989:2).

Karena begitu pentingnya aspek kosakata dalam pembelajaran bahasa asing maka dalam pengajarannya perlu menggunakan metode dan strategi tertentu agar dapat mencapai hasil belajar yang diinginkan. Metode akan dianggap efektif apabila metode tersebut menghasilkan minat dan kemampuan peserta didik. Penggunaan metode yang tepat akan menentukan efektivitas dan efisiensi pembelajaran (Mulyana, 2002: 107).

Anak-anak di beberapa umur yang berbeda pada dasarnya senang mendengarkan, menyanyikan dan belajar dengan nyanyian/lagu. Oleh karena itu musik secara umum adalah bagian penting dari proses belajar-mengajar bagi siswa kanak-kanak. Hampir seluruh bentuk nyanyian dari yang tradisional sampai dengan yang trend dapat dimanfaatkan oleh guru dalam pembelajaran. Suatu hal yang peenting diperhatikan adalah bahwa guru hendaknya 
dapat memilih/menyeleksi atau menciptakan lagu yang bisa digunakan baik untuk menyanyi bersama mauun dalam bernyanyi sambil melakukan kegiatan (Muhaiban, 2002:5).

Oleh karena itu hendaknya guru anak usia dini menerapkan pembelajaran kosakata bahasa Arab dengan teknik bernyanyi. Hal yang perlu diperhatikan guru dalam memilih lagu adalah dengan tema lagu yang sesuai dengan dunia anak dan lagu tidak terlalu panjang agar anak-anak mudah mengingatnya.

Hal tersebut juga tidak lepas dari kasus metode pembelajaran dalam meningkatkan hafalan kosakata peserta didik RA Al-Junaidiyah Biru Bone. Dari observasi awal yang telah dilakukan oleh penulis di RA Al-Junaidiyah Biru Bone kaya akan penerapan metode pembelajaran termasuk pembelajaran bahasa Arab khususnya lagi dalam penguasaan kosakata bahasa Arab. Penulis tertarik untuk mengamati sejauh mana proses yang dilakukan guru di sekolah tersebut dalam penerapan teknik bernyanyi.

\section{Metode Pembelajaran Bernyanyi}

Secara etimologi, metode berasal dari kata method yang artinya suatu cara kerja yang sistematis untuk memudahkan pelaksanaan kegiatan dalam mencapai suatu tujuan. Metode pembelajaran dapat pula diartikan sebagai suatu cara yang sistematis untuk melakukan aktivitas atau kegiatan pembelajaran yang tujuannya mempermudah dalam mencapai tujuan pembelajaran yang diinginkan. Pendapat lain mengatakan bahwa metode pembelajaran ialah suatu cara atau sistem yang digunakan dalam pembelajaran yang bertujuan agar anak didik dapat mengetahui, memahami, mempergunakan, dan menguasai bahan pelajaran tertentu (Fadhillah, 2012:161).

Metode bernyanyi merupakan metode pembelajaran yang menggunakan syair-syair yang dilagukan. Biasanya syair-syair tersbut disesuaikan dengan materi-materi yang akan diajarkan oleh pendidik. Memurut bebrapa ahli, bernyanyi membuat suasana belajar menjadi riang dan bergairah sehingga perkembangan anak dapat distimmulasi secara lebih optimal. (Fadlillah, 2012:175).

Menurut Bonnie dan John (dalam Prasetya, 2010:22) terdapat manfaat dari metode menyanyi yaitu membantu mencapai kemampuan dalam pengembangan daya pikir, membantu menyalurkan emosi seperti senang atau sedih melalui isi syair lagu/nyanyian, dan membantu menambah perbendaharaan kata baru melalui syair lagu/ nyanyian. Berikut adalah beberapa manfaat yang bisa diambil dari anak bernyanyi antara lain: 
1. melatih motorik kasar

2. membentuk rasa percaya diri anak

3. menemukan bakat anak

4. melatih kognitif dan perkembangan bahasa anak.

Selain memiliki manfaat yang penting bagi siswa, metode bernyanyi ini juga memiliki kelebihan dan kelemahan. Kelebihan dari metode menyanyi yaitu mampu membantu siswa untuk mengembangkan, memperbanyak kesiapan serta penguasaan keterampilan dalam proses kognitif atau pengenalan siswa. Disamping itu, metode menyanyi dapat membangkitkan semangat kegairahan belajar para siswa, memberikan kesempatan kepada siswa untuk berkembang dan maju sesuai dengan kemampuannya masing-masing, serta mampu mengarahkan cara belajar siswa, sehingga lebih memiliki motivasi yang kuat untuk belajar lebih giat (Masykur, 2004:69).

Beberapa penelitian terdahulu telah membahas tentang penerapan metode bernyanyi dalam pembelajaran di kelas, di antaranya:

Barokatussolihah, dalam tulisannya yang berjudul "Upaya Meningkatkan Penguasaan Mufrodat Bahasa Arab melalui Metode Bernyanyi di Kelas VII A MTsN Donomulyo Kulon Progo". Tulisan ini ditujukan untuk meningkatkan hasil belajar siswa dalam pembelajaran Bahasa Arab terutama keterampilan menguasai mufrodat melalui metode Bernyanyi. Penelitian ini dilaksanakan di MTsN Donomulyo Nanggulan Kulon Progo dengan mengambil sampel kelas VII A yang berjumlah 21 siswa Tahun Pelajaran 2014/2015. Penguasaan mufrodat siswa di kelas ini ketika dengan menggunakan metode Bernyayi mengalami peningkatan.

Selanjuitnya, Khoirotun Ni'mah dalam tulisannya yang berjudul "Penggunaan Teknik Bernyanyi untuk Meningkatkan Penguasaan Kosa-Kata Bahasa Arab pada Anak Usia Dini”. Penelitian ini bertujuan untuk meningkatkan pemerolehan kosakata bahasa Arab pada anak usia dini dengan teknik bernyanyi. Anak-anak dalam berbagai umur pada dasarnya senang mendengarkan, menyanyikan dan belajar dengan nyanyian/lagu. Oleh karena itu musik secara umum merupakan bagian penting dari proses belajarmengajar bagi siswa kanak-kanak. Hasil penelitian menunjukkan bahwa siswa anak usia dini senang belajar bahasa Arab dengan bernyanyi dan lebih mudah mengingat kosakata yang telah diajarkan oleh guru. Dengan demikian dapat disimpulkan bahwa teknik bernyanyi mampu meningkatkan penguasaan kosakata bahasa Arab anak usia dini. 
Berikutnya, Wiwin Fachrudin Yusuf dan Imatuzzahiro dalam tulisannya "Metode Bernyanyi Arab dengan Menggunakan Media Eraser Walk dalam Meningkatkan Hafalan Kosakata Bahasa Arab". Dalam penelitian ini di Madin Manarul Mubarokah dalam pengajaran bahasa Arab menggunakan metode bernyanyi Arab dengan menggunakan media Eraser Walk, dimana metode ini sangat membantu siswa untuk menambah atau mengasah kemampuan mengingat kosakata karena dibuat permainan dan menyenangkan siswa. Dari permainan ini bisa membuat siswa merasa senang dan enjoy ketika menggunakan metode ini.

Berdasarkan tinjauan pustaka yang ada akan terlihat jelas bahwa tulisan dalam penelitian ini lebih mengarah pada variasi metode bernyanyi dalam penerapan teknik bernyanyi untuk meningkatkan penguasaan kosakata bahasa Arab siswa RA Al-Junaidiyah Biru Bone.

\section{Pengertian Pembelajaran Bahasa Arab}

Kegiatan pembelajaran sebagai proses yang identik dengan kegiatan mengajar yang dilakukan guru dan murid agar terjadi kegiatan belajar. Pengertian pembelajaran adalah suatu upaya membelajarkan siswa untuk belajar yang mana guru bertindak sebagai fasilitator untuk membelajarkan siswa. Belajar adalah kegiatan yang berproses dan merupakan unsur yang sangat fundamental dengan penyelenggaraan jenis dan tingkat pendidikan (Muzayyin Arifin, 2003: 21).

Pembelajaran merupakan suatu upaya guru sebagai fasilitator untuk membelajarkan siswa untuk memperoleh tujuan yang ingin dicapai. Menurut Nana Sudjana bahwa pembelajaran adalah setiap upaya yang sistematis dan disengaja oleh pendidik untuk menciptakan kondisi-kondisi agar peserta didik melakukan kegiatan pembelajaran. Dalam pembelajaran bahasa Arab hendaknya mengacu pada upaya membina dan mengembangkan keempat segi kemampuan bahasa, yaitu: kemampuan menyimak (istima'), berbicara (takallum), membaca (qiro'ah), dan menulis (kitabah), agar mampu memahami bahasa, baik melalui pendengaran maupun tulisan (reseptif), dan mampu mengutarakan pikiran dan perasaan (Ahmad Muhtadi Anshor, 2009: 15).

\section{Tujuan Pembelajaran Bahasa Arab}

Pembelajaran bahasa diperlukan agar seseorang dapat berkomunikasi dengan baik dan benar kepada sesamanya dan lingkungannya, baik secara lisan maupun tulisan. Tujuan pembelajaran bahasa Arab adalah untuk menguasai ilmu bahasa dan kemahiran berbahasa 
arab, seperti muthala"ah, muhadatsah, insya", nahwu dan sharaf, sehingga memperoleh kemahiran berbahasa yang meliputi empat aspek kemahiran, yaitu: kemahiran menyimak, kemahiran membaca, kemahiran menulis, dan kemahiran berbicara (Muhammad Mustari, 2014: 15).

Kemahiran berbahasa meliputi kemahiran menyimak, kemahiran membaca, kemahiran menulis, dan kemahiran berbicara. Menyimak merupakan proses perubahan wujud bunyi (bahasa) menjadi wujud makna. Kemahiran membaca yaitu kemahiran berbahasa yang sifatnya reseptif, menerima informasi dari orang lain di dalam bentuk tulisan. Kemahiran menulis yaitu kemahiran bahasa yang sifatnya yang menghasilkan atau memberikan informasi kepada orang lain (pembaca) di dalam bentuk tulisan. Dan kemahiran berbicara yaitu kemahiran yang sifatnya produktif, menghasilkan atau menyampaikan informasi kepada orang lain di dalam bentuk bunyi bahasa sebagai proses perubahan wujud bunyi bahasa menjadi wujud tuturan.

Pembelajaran bahasa Arab sangat penting dalam ajaran agama Islam. Tujuan umum pembelajaran bahasa Arab adalah: 1). Untuk dapat memahami al-Quran dan hadist sebagai sumber hukum ajaran islam, 2) Untuk dapat memahami buku-buku agama dan kebudayaan islam yang ditulis dalam bahasa Arab, 3) Untuk dapat berbicara dan mengarang dalam bahasa (Rahmat Rahardjo, 2010: 11).

Tujuan pembelajaran merupakan sasaran yang hendak dicapai pada akhir pengajaran, serta kemampuan yang harus dimiliki siswa. Menurut Oemar Hamalik, tujuan penting dalam rangka sistem pembelajaran yakni merupakan suatu komponen sistem pembelajaran yang menjadi titik tolak dalam merancang sistem yang afektif. Adapun tujuan khusus dalam pembelajaran bahasa Arab adalah : 1) Untuk memahami dan memahamkan ajaran Islam, 2) Untuk memahami ilmu dan ketrampilan Bahasa, 3). Sebagai alat untuk mempelajari dan memperdalam pengetahuan Islam, seperti sejarah masa lalu, berita-berita, naskah-naskah tua guna menyelidiki latar belakang sejarah manusia, kebudayaan dan adat istiadat serta perkembangan bahasa itu sendiri, 4) Untuk berkomunikasi dalam kehidupan sehari-hari, dalam forum ilmiyah, maupun dalam forum-forum resmi.

\section{Pentingnya Pembelajaran Bahasa Arab}

Bahasa Arab sangat berkaitan erat dengan sumber hukum Islam yaitu Alqurean dan hadits. Pentingnya Bahasa Arab tercantum dalam al-Qur'ean surat Yusuf 12: 2. Sebagaimana 
Allah telah menjadikan bahasa Arab sebagai bahasa Al-Qurean karena bahasa Arab adalah bahasa terbaik yang pernah ada.

"Sesungguhnya Kami menurunkannya berupa Al Quran dengan berbahasa Arab, agar kamu memahaminya."(Q.S. Yusuf:2)

Kedudukan istimewa yang dimiliki bahasa arab diantara bahasa-bahasa lain di dunia karena berfungsi sebagai bahasa al-Qurean dan al-Hadits serta kitab-kitab lainnya. Itulah sebabnya, maka di dalam kitab Faid Al-Qadar Syarh Al-Jami Al-Sagir susunan al-manawiy (1976:178), disebutkan bahwa dari ibnu abbas dengan riwayat muslim.

Bahasa Arab memiliki pengaruh yang sangat besar dalam kehidupan, akhlak, dan agama. Orang yang pandai bahasa Arab cenderung senang membaca kitab-kitab para ulama yang berbahasa Arab dan tentu senang juga membaca dan menghafal Al-Qurean serta hadits-hadits Rasulullah. Berbeda dengan orang yang pandai berbahasa Inggris (namun tanpa dibekali dengan ilmu agama yang baik), dia cenderung senang membaca buku berbahasa Inggris yang jelas kebanyakannya merupakan karya orang kafir. Sehingga mulailah ia mempelajari kehidupan orang kafir sedikit demi sedikit. Mau tidak maudiapun harus mempelajari cara pengucapan dan percakapan yang benar melalui mereka, agar dia bisa memperbagus bahasa Inggrisnya.

Bahasa Arab adalah bahasa Agama Islam dan bahasa Al-Qur"ean. Seseorang tidak akan dapat memahami kitab dan sunnah dengan pemahaman yang benar dan selamat (dari penyelewengan) kecuali dengan bahasa Arab. Menyepelekan dan menggampangkan Bahasa Arab akan mengakibatkan lemah dalam memahami agama serta jahil (bodoh) terhadap permasalahan agama.

\section{METODE PENELITIAN}

Penelitian ini menggunakan pendekatan kualitatif yaitu penelitian yang bermaksud untuk memahami fenomena tentang apa yang dialami oleh subjek penelitian misalnya perilaku, persepsi, motivasi, dan tindakan secara holistik dan dengan cara deskripsi dalam bentuk kata-kata dan bahasa pada suatu konteks khusus yang alamiah (Meleong 2013: 6).

Penelitian ini menggunakan pendekatan kualitatif karena adanya keunikan metode bernyanyi dalam meningkatkan mufradat dalam pembelajaran bahasa Arab di RA Ma'had Hadits Al-Junaidiyah Biru Bone. Keunikan tersebut yakni karena program RA Ma'had Hadits Al-Junaidiyah Biru Bone memiliki banyak kegiatan kebahasaan untuk penunjang pengembangan bakat dan keterampilan peserta didik terutama dalam kosakata (mufradat) 
bahasa Arab. pembelajaran bahasa Arab menggunakan teknik bernyanyi sangat membantu anak usia dini untuk menghafal kosakata-kosakata dalam bahasa Arab. Dapat dilihat dari hafalan nyanyian yang mana lirik lagunya sudah diganti dengan kosakata bahasa Arab. dan masih banyak kegiatan lain yang mengasah peserta didik dalam berbahasa Arab.

Segala bentuk cara yang digunakan untuk memperoleh data-data yang dibutuhkan dalam sebuah penelitian. Adapun beberapa teknik pengumpulan data yang peneliti gunakan yaitu berupa observasi, tes, wawancara, dan dokumentasi.

\section{Subjek dan Informan Penelitian}

Dalam penelitian ini diperlukan adanya subjek penelitian secara langsung yang dapat dijadikan sebagai narasumber dalam penelitian. Subjek penelitian memberikan informasi tentang pembelajaran/ kegiatan bahasa Arab di RA Raodhatul Athfal Ma'had Hadits AlJunaidiyah Biru Bone. Subjek penelitian ini adalah Guru Bahasa Arab dan Kepala Madrasah RA Raodhatul Athfal Ma'had Hadits Al-Junaidiyah Biru Bone. .

\section{Metode Pengumpulan Data}

Dalam pengumpulan data, penelitian ini menggunakan beberapa metode pengumpulan data antara lain sebagai berikut:

\section{Observasi}

Observasi atau pengamatan biasanya digunakan dalam penelitian deskriptif. Selain itu juga digunakan untuk mengukur tingkah laku individu, ataupun proses terjadinya sesuatu yang dapat diamati, baik dalam situasi alami atau buatan (Nana Sudjana, 1989: 109). Observasi dilakukan untuk mengamati aktivitas meliputi kegiatan-kegatan pembelajaran bahasa Arab di RA Raodhatul Athfal Ma'had Hadits Al-Junaidiyah Biru Bone.

\section{Wawancara (interview)}

Wawancara adalah bertukar informasi atau ide melalui tanya jawab, sehingga dapat dikonstruksikan makna dalam suatu topik tertentu. Wawancara digunakan sebagai teknik pengumpulan data untuk mengetahui informasi secara mendalam yang dilakukan baik dengan cara bertatap muka secara langsung maupun dengan telepon.

\section{Dokumentasi}

Metode dokumentasi merupakan suatu teknik pengumpulan data dengan menghimpun dan menganalisis dokumen-dokumen, baik dengan dokumen tertulis, gambar, maupun elektronik (Nana Saodih, 2009: 221). Metode ini digunakan untuk mencari dokumen tentang profil, visi, misi, serta tujuan RA Raodhatul Athfal Ma'had Hadits Al-Junaidiyah 
Biru Bone., data guru, data siswa, program kerja kegiatan di asrama, dan dokumen lain yang relevan dan berpengaruh terhadap pembelajaran bahasa Arab di RA Raodhatul Athfal Ma'had Hadits Al-Junaidiyah Biru Bone.

\section{Pemeriksaan Keabsahan Data}

Teknik yang digunakan adalah teknik triangulasi, yaitu menggabungkan beberapa teknik pengumpulan data dan sumber data yang telah ada. Menurut Djam ${ }^{\text {ee }}$ an Satori (2012: 170). Metode triangulasi diartikan sebagai teknik pengumpulan data yang bersifat menggabungkan dari berbagai teknik pengumpulan data dan sumber data yang telah ada. Adapun dalam penelitian ini, peneliti menggunakan triangulasi teknik dan triangulasi sumber data.

\section{Teknik Analisa Data}

Dalam penelitian kualitatif, proses analisis data harus dilakukan pada waktu yang bersamaan dengan pengumpulan data. Dan apabila hal itu tidak dilakukan maka akibatnya peneliti akan banyak meghadapi kesulitan karena banyaknya data yang berupa diskripsi kalimat. Dalam penelitian ini, model analisis data yang digunakan adalah analisis interaktif.

\section{HASIL DAN PEMBAHASAN}

Proses pembelajaran dalam penelitian dengan menggunakan teknik bernyanyi karena bernyanyi merupakan kegiatan yang digemari anak dalam berbagai umur, sehingga dalam pembelajaran bahasa Arab anak-anak lebih mudah menguasai kosakata serta menumbuhkan semangat anak dalam belajar bahasa Arab. Berdasarkan penelitian yang dilakukan oleh peneliti ada beberapa temuan yang diperoleh bahwa pembelajaran bahasa Arab menggunakan teknik bernyanyi sangat membantu anak usia dini untuk menghafal kosakatakosakata dalam bahasa Arab. Dapat dilihat dari hafalan nyanyian yang mana lirik lagunya sudah diganti dengan kosakata bahasa Arab.

Observasi merupakan langkah awal yang dilakukan oleh peneliti dalam penelitian ini. Observasi adalah instrument yang sering digunakan dalam penelitian di bidang pendidikan. Dalam penelitian ini peneliti menggunakan dua panca inderanya yaitu penglihatan dan pendengaran. Observasi akan lebih efektif jika informasi yang hendak diambil berupa kondisi atau fakta alami, tingkah laku dan hasil kerja anak didik dalam situasi alami. Dalam hal ini peneliti mengamati proses belajar, cara melafalkan dan penguasaan kosakata selama pembelajaran berlangsung. 
Observasi dilakukan di RA Raodhatul Athfal Ma'had Hadits Al-Junaidiyah Biru Bone., dari obsevasi tersebut data yang dhasilkan oleh peneliti adalah bahwa siswa RA Raodhatul Athfal Ma'had Hadits Al-Junaidiyah Biru Bone. belum diajarkan materi bahasa Arab hanya terkadang diajari lagu bahasa Arab tentang angka dan anak-anak antusias sekali dalam menyanyikan lagu tersebut.

\section{Penerapan Metode Bernyanyi dalam Pembelajaran Bahasa Arab di RA Raodhatul} Athfal Ma'had Hadits Al-Junaidiyah Biru Bone.

Anak-anak dalam berbagai umur pada dasarnya senang mendengarkan, menyanyikan, dan belajar dengan nyanyian/lagu. Oleh karena itu musik secara umum merupakan bagian penting dari proses belajar-mengajar bagi siswa kanak-kanak. Hampir semua bentuk nyanyian dari yang tradisional sampai dengan yang pop dapat dimanfaatkan oleh guru dalam pembelajaran. Hal yang perlu diperhatikan adalah bahwa guru hendaknya dapat memilih/menyeleksi atau menciptakan lagu yang dapat digunakan baik untuk menyanyi bersama maupun bernyanyi sambil melakukan kegiatan (Muhaiban, 2002:5). Oleh karena itu, peneliti mencoba mengamati metode bernyanyi untuk pembelajaran bahasa Arab pada anak usia dini di RA Raodhatul Athfal Ma'had Hadits Al-Junaidiyah Biru Bone.

Hal-hal yang perlu diperhatikan dalam memilih lagu untuk pembelajaran ALA antara lain berikut ini:

1. Syair atau kata-kata dalam lagu hendaknya jelas

2. Bahasa yang digunakan dalam lagu tersebut tidak terlalu sulit

3. Tema lagu dipilih yang sesuai dengan dunia anak

4. Lagu tidak terlalu panjang

5. Lagu diupayakan memiliki keterkaitan dengan materi yang diajarkan indra pendengaran dan penglihatan, sedangkan guru memerlukan contoh seperti gambar anggota tubuh, gambar angka, gambar hewan atau yang lain sesuai materi yang diajarkan oleh guru di kelas Dalam pembelajaran ini Alat yang diperlukan anak didik ketika pembelajaran berlangsung yaitu: alat panca.

Dalam pembelajaran kali ini guru akan mengajarkan tentang anggota tubuh. Langkah yang dilakukan guru adalah sebagai berikut:

1. Mengucap salam, berdoa sebelum belajar, bernyanyi tentang lagu anak-anak.

2. Bercakap-cakap kepada anak tentang nama-nama anggota tubuh.

3. Menunjukkan kepada anak contoh gambar anggota tubuh. 
4. Guru mengajak anak didik mendengarkan dan menirukan guru menyanyikan nama-nama anggota tubuh dengan bahasa Arab menggunakan lagu anak gembala.

5. Anak didik mengikuti langkah demi langkah hingga dapat menirukan guru seperti yang diperintahkan guru

6. Setelah itu guru mengajukan pertanyaan, tentang nama benda yang dicontohkan oleh guru tadi.

7. Lalu guru mengucapkan nama anggota tersebut dalam Bahasa Arab satu persatu.

8. Anak mengikuti dan melafalkan kata yang dicontohkan guru, dan guru harus sabar dan teliti mengoreksi ucapan/pelafalan anak yang kurang tepat setelah anak-anak mencoba menirukan ucapan guru.

9. Guru mengobservasi, menilai dan menganalisis hasil pembelajaran dengan metode bernyanyi.

\section{KESIMPULAN}

Anak-anak dalam berbagai umur pada dasarnya senang mendengarkan, menyanyikan, dan belajar dengan nyanyian/lagu. Oleh karena itu musik secara umum merupakan bagian penting dari proses belajar-mengajar bagi siswa kanak-kanak. Hampir semua bentuk nyanyian dari yang tradisional sampai dengan yang pop dapat dimanfaatkan oleh guru dalam pembelajaran. Hal yang perlu diperhatikan adalah bahwa guru hendaknya dapat memilih/menyeleksi atau menciptakan lagu yang dapat digunakan baik untuk menyanyi bersama maupun bernyanyi sambil melakukan kegiatan. Oleh karena itu, peneliti mencoba menggunakan teknik bernyanyi untuk pembelajaran bahasa Arab pada anak usia dini.

Dengan demikian dapat disimpulkan bahwa RA Raodhatul Athfal Ma'had Hadits AlJunaidiyah Biru Bone yang menggunakan teknik bernyanyi dalam pembelajaran bahasa Arab dan kelas sebagai solusi alternatif dalam meningkatkan penguasaan kosakata bahasa Arab pada anak usia dini karena pada dasarnya anak-anak suka bernyanyi sehingga alangkah lebih baiknya jika dalam pembelajaran diterapkan belajar sambil bernyanyi atau bernyanyi sambil belajar. 


\section{DAFTAR PUSTAKA}

Arifin, Muzayyin. (2003). Kapita Selekta Pendidikan Islam. Jakarta: PT Bumi Aksara.

Barokatussolihah, (2016). Upaya Meningkatkan Penguasaa Mufradat Bahasa Arab Melalui Metode Bernyanyi Di Kelas VII A MTsN Donomulyo Kulon Progo. Jurnal Pendidikan Madrasah, 1(1). 32

Darmawan, D. (2013). Metode Penelitian Kuantitatif. Bandung: Remaja Rosdakarya.

Hidayati, N. \& Ridwan, N.A. (2005). Strategi Pembelajaran Bahasa Arab Untuk Anak. Skripsi. Malang: Jurusan Sastra Arab Fakultas Sastra Universitas Negeri Malang.

Khoiruddin. (2017). Pengenalan Bahasa Arab melalui Nyanyian pada Anak Usia Prasekolah di PAUD Terpadu Ihyaul Ulum Puncu Kediri Jatim, Jurnal Obsesi: Jurnal Pendidikan Anak Usia Dini, 1(1)

Khulli, M. Ali. (1986). Assaliiba Tadaris Al-Lughoh Al-Arabiyah. Jakarta: Al-Adeeb Library.

Muhaiban. (2002). Strategi Pembelajaran Al-Arabiyah Lil-Athfal. Malang: Makalah disajikan Dalam Pelatihan Pembelajaran Bahasa Arab Untuk Anak di Fakultas Sastra Universitas Negeri Malang.

Muhtadi Anshor, Ahmad. (2009). Pengajaran Bahasa Arab. Yogyakarta.

Mustari, Muhammad. (2014). Manajemen Pendidikan. Jakarta: PT Raja Grafindo.

Mulyana. (2002). Menjadi Guru Profesional. Bandung: PT Remaja Rosdakarya.

Musbikin, I. (2007). Mendidik Anak Kreatif Ala Eisastein. Yogyakarta: PT Mitra Pustaka.

Rohmat. (2017). Proses Mengajar Belajar Berkualitas Perspektif Pendidikan Islam Pengawal Pancasila. Yogyakarta: Gerbang Media.

Sugiono. (2009). Metode Penelitian Pendidikan (Pendekatan Kualitatif, Kuantitatif, $R$ \& D). Bandung: ALFABETA.

Syamsuddin, A.R, \& Vismia, D. (2007). Metode Penelitian Pendidikan Bahasa. Bandung: Remaja Rosda Karya.

Tarigan, G.H. (1989). Pengajaran Kosakata. Bandung: Angkasa.

Qomaruddin A. (2017). Penerapan Metode Bernyanyi dalam Pembelajaran Mufradat. Jurnal Tawadhu 1(2), 2017.

Wiriatmaja, R. (2005). Metode Penelitian Tindakan Kelas. Bandung: Rosda Karya. 